\title{
COMESA: Prospects and Challenges for Regional Trade Integration
}

\author{
Solomon Girma Taddesse Hailu Abebe Endale \\ School of Law, Madda Walabu University, PO Box 247, Bale Robe ,Ethiopia
}

\begin{abstract}
The Common Market for Eastern and Southern Africa (COMESA) was established with a view to achieve sustainable development through progressive realization of integration, begin with preferential trade area then becoming a common market and finally transforming into economic community. In COMESA, member states have been obligated to establish a customs union, abolish all non-tariff barriers, and determine a common external tariff and follow common standards of custom procedures. Among those commitments, FTA is established to facilitate regional integration through zero customs tariffs on goods traded among the Member States. The study has found that, less diversity in trade, overlapped memberships, heterogeneity of the economy, loss of import-export tax revenue, lack of political commitment, loss of national sovereignty, poor private sector participation, and poor infrastructure were identified as challenge to achieve the objective of COMESA. Therefore, states needs to take affirmative action's including harmonizing their national trade policies in the manner of pre portrayed goal of COMESA-FTA arrangement. In doing so, it needs to venture the expected challenges of membership to COMESA-FTA and potential gains from trade liberalization.
\end{abstract}

Keywords: COMESA, Regional Integration, Free Trade Area

DOI: $10.7176 / \mathrm{IAGS} / 76-02$

Publication date:September $30^{\text {th }} 2019$

\section{Introduction}

Regional integration arrangements in Africa have a long history, dating back to the establishment of the South African Customs Union (SACU) in 1910 and the East African Community (EAC) in 1919. ${ }^{1}$ The arrangements became fashionable and high on the agenda of Africa's policy makers since independence in the $1950 \mathrm{~s}^{2}{ }^{2}$ The interest towards the issue has been renewed to create strong regional economic integration (REI) mechanisms to promote economic growth, after the end of cold war and with the emergency of powerful trading blocs. ${ }^{3}$

According to ECA, although currently the African Union recognizes eight regional economic Communities as the building blocks of the African economic community, Africa has 14 major regional economic groupings ${ }^{4}$ United Nations conference on trade and development disclosed that intra-Africa trade 2004 to 2006 is $8.68 \%$ which is by far low in comparison to intra trade between developing countries of Asia and America, $45.54 \%$ \& $18.54 \%$ respectively. ${ }^{5}$ In a similar way to Africa, Intra-COMESA trade is in its infancy stage which however is showing a significant progress currently.

The Common Market for Eastern and Southern Africa traces its genesis to the mid-1960s. ${ }^{6}$ In 1965, the United Nations Economic Commission for Africa convened a ministerial meeting of the then newly independent states of Eastern and Southern Africa has considered the proposal for the establishment of a mechanism to the promote sub-regional economic integration. ${ }^{7}$ In 1978, at a meeting of Ministers of Trade, Finance and Planning in Lusaka, the creation of a sub-regional economic community was recommended, beginning with a sub-regional preferential trade area which would be gradually upgraded over a ten-year period to a common market until the community had been established. ${ }^{8}$

Consequently the treaty establishing preferential trade area (PTA) was signed on 21st December 1981 in Lusaka. The PTA Treaty envisaged its transformation into a Common Market and, in conformity with this, the treaty establishing the Common Market for Eastern and Southern Africa, COMESA, was signed on 5th November 1993 in Kampala, Uganda and was ratified a year later in Lilongwe, Malawi on 8th December 1994. ${ }^{9}$

\footnotetext{
1 Alemayehu, G. \& Haile, K. (2007). Regional Economic Integration in Africa: A Review of Problems and Prospects with a Case Study of COMESA. Journal of African Economies , 17 (3). p.378.

2 Gibb, R. (2009). Regional Integration and Africa's Development Trajectory: Meta theories, Expectations and Reality. Third World Quarterly, 30 (4). p. 702.

3 Baldwin, R. (1997). Review of Theoretical Developments on Regional Integration, Regional Integration and trade liberalization in Sub Saharan Africa. In B. a. Lows (Ed.). AERC Publication, as cited by Mengesha, Y. (2009). Trade Effects of Regional Economic Integration in Africa: The Case of SADC. Debre Birhan, Ethiopia. p.2.

${ }^{4}$ UNECA. (2007). Report to Fifth Session of Committee on Trade \& Regional Integration. UNECA, Addis Ababa. p. 77

${ }^{5}$ UNCTAD. (2009). Economic Development in Africa Report 2009: Strengthening Regional Economic Integration for Africa's Development. United Nations Conference on Trade and Development. Geneva: UN Publication. p 23.

${ }^{6}$ Retrieved 05 02, 2018, from http://www.comesa.int/history-of-comesa/

7 Ibid.

8 Ibid.

${ }^{9}$ Ibid.
} 
The regional agreement currently involves 19 members of African states including Ethiopia. Different studies signified the possible positive and negative consequences of regional trade agreements.

Accordingly, new trade opportunities, larger markets, increased bargaining power in multilateral negotiations and increased foreign direct investment flow in the region were among its positive effects. ${ }^{1}$ Furthermore, competition which results from regional free trade agreement is likely to ensure that domestic producers become more efficient through the development and utilization of new technology and also larger market results in lower production costs. ${ }^{2}$ Conversely, regional integration diverts trade by replacing initially cheaper imports from a non-member country with more expensive imports from a member country within the region $^{3}$ and a history of very limited success in replacing lost trade taxes with revenue from other sources ${ }^{4}$ was some of the negative fallouts.

Regional integration is considered as one of the prominent strategies for development among countries and regions. For this reason, there was a consensus between African countries which had gained political independence in the 1950's to promote economic co-operation among them. Accordingly, significant commitment for the establishment of regional economic community made including PTA- COMESA, aimed at accelerating the integration of African economies ${ }^{5}$. The preamble ${ }^{6}$ of the treaty explicates that, COMESA was established with a view to achieve sustainable development and convergence of economy through the attainment of full market integration. The arrangement also intended to attain sustainable growth and development of the Member States, joint adoption of macroeconomic policies and programs, raising the standard of living of its peoples, to cooperate in the creation of an enabling environment for investment, to co-operate in the promotion of peace, security and stability and to contribute towards the establishment, progress and the realization of the objectives of the African Economic Community. ${ }^{7}$

The community intends in progressive realization of integration with adequate flexibilities for members to consider their economic development in making commitments. ${ }^{8}$ The integration scheme is designed to have three phases. The first phase relates to the establishment of a preferential trade area. This is followed by the conversion of this trade area into a common market. Finally, the common market will then be converted into an economic community. ${ }^{9}$ COMESA has successfully established a Free Trade Area (FTA) on 31 October 2000 with the key aim being to facilitate regional integration through zero customs tariffs on goods traded among the Member States. It also launched its Customs Union in June 2009 and envisaged to become full Economic Community by $2025 .^{10}$

In order to realize the aims and objectives of COMESA, the member states have made specific undertakings to establish a customs union, abolish all non-tariff barriers to trade among themselves, and establish a common external tariff and to co-operate in customs procedures and activities. ${ }^{11}$ The policy basis of these undertakings is that there is need to liberalize trade in the region and to promote customs co-operation. ${ }^{12}$ Other specific undertakings made by COMESA member states relate to transport and communications, industry and energy, monetary affairs and finance, agriculture, and economic and social development. ${ }^{13}$ Also, member states recognize that dumping, by which products of a member state are introduced into the commerce of another member state at less than the normal value of the products, is to be prohibited if it causes or threatens material injury to an established industry in the territory of the other member state, or materially retards the establishment of a domestic industry. ${ }^{14}$

\section{Methodology}

The study was conducted based on doctrinal legal research methodology that has been used both primary and secondary sources. Under the primary sources, regional and sub-regional conventions were consulted. On the

\footnotetext{
${ }^{1}$ Martha, B. H. (2014). Regional Economic Integration in Africa: Challenges and Prospects. Mizan Law Review, 8(2). pp. 307-308

2 Patel, C. (2011). Challenges and Opportunities of Regional Trading Agreements in Africa. In R. Modi (Ed.), International Political Economy Series. London: Palgrave Macmillan, South-South Cooperation. p. 139

${ }^{3}$ Hansohm, D. (2000). Potentials of Regional Integration in Africa, as cited by Martha, B. (2014). Regional Economic Integration in Africa: Challenges and Prospects. Mizan Law Review, 8(2). p. 305

${ }^{4}$ Khandelwal, P. (2004). COMESA and SADC: Prospects and Challenges for Regional Trade Integration (IMF Working Paper). p.4

${ }^{5}$ COMESA. (2016). Medium term strategic plan 2016-2020; In Pursuit of Regional Economic Transformation and Development. COMESA Secretariat, Zambia, Lusaka. p.6

${ }^{6}$ Para $6 \& 7$ of Preamble of the treaty establishing COMESA, signed on 5th November 1993 in Kampala, ratified a year later in Lilongwe, on 8th December 1994. Herein after called COMESA treaty

${ }^{7}$ Id., Article 3

${ }^{8}$ Mehreteab, G. G. (2013). Integration of the Ethiopian Financial Service Sector through Regional Financial Arrangements: A Step before WTO Accession?'. Law, Social Justice \& Global Development Journal (LGD).p 11

${ }^{9}$ Mwenda, K. K. (1997). The law on regional integration in southern and eastern Africa: threats and prospects. SA Public Law , 12 (2). p. 455

${ }^{10}$ COMESA, Supra note 13, p.7

${ }^{11}$ Article 4(1a) of the COMESA Treaty

${ }^{12}$ Id., Article 4(1).

${ }^{13}$ Id., Article 4(1-5).

${ }^{14}$ Id., Article 51.
} 
secondary sources, the article has given emphases on the investigation of the pertinent literatures on the subject area including books, academic articles and various internet sites have been assessed.

\section{Structural Framework of COMESA}

\subsection{The Authority}

The Authority is the supreme organ ${ }^{1}$ of the Common Market and is composed of the Heads of States and Government of all 19 Member States of COMESA. The authority is responsible for the general policy and direction and control of the performance of the executive functions of the Common Market and the achievement of its aims and objectives of the arrangement. ${ }^{3}$ The Authority shall meet once every year and may hold extraordinary meetings at the request of any member of the Authority. ${ }^{4}$

\subsection{The Council of Ministers}

The Council of Ministers of the Common Market shall consist of Ministers designated by each Member State. ${ }^{5}$ It is principally responsible for overseeing the functioning and development of COMESA and ensuring the implementation of agreed policies ${ }^{6}$. Furthermore, the various COMESA institutions are premeditated by the Council. $^{7}$

\subsection{The Court of Justice}

The COMESA Court is established to ensure the adherence of law in the interpretation and application of the Treaty. ${ }^{8}$ The Court of Justice shall consist of a first instance division and an appellate division. ${ }^{9}$ The Court shall be composed of twelve judges appointed by the authority of which seven shall be appointed to the First Instance Division and five shall be appointed to the Appellate Division. ${ }^{10}$ The Judges of the Court shall be chosen from among persons holding of high judicial office in their respective countries or who are jurists of recognized competence. $^{11}$

\subsection{The Committee of Governors of Central Banks}

Article 13 of the COMESA treaty also established the Committee of Governors of Central Banks which shall consist of the governors of the monetary authorities designated for that purpose by the Member States. The committee is responsible for the development of programs and action plans in the field of finance and monetary co-operation ${ }^{12}$, monitor and keep under constant review and ensure the proper implementation of the programs, ${ }^{13}$ consider reports and recommendations from the Technical Committee on finance and monetary affairs, ${ }^{14}$ submit from time to time, reports and recommendations to the Council concerning the implementation of the Finance and Monetary Co-operation program. ${ }^{15}$

\subsection{The Inter-Governmental Committee}

The Intergovernmental Committee shall consist of such permanent or principal secretaries as may be designated by each member state ${ }^{16}$. The committee develops the program and action plans in all sectors of co-operation, except in the finance and monetary sectors. ${ }^{17}$ The committee is also required to monitor, constantly review the functioning and development of the common market and to oversee the implementation of the program in accordance with the provisions of the treaty ${ }^{18}$. In exercising this power, the committee may request a technical committee to investigate any particular issue, or the Secretary-General to undertake some specific investigations. ${ }^{19}$

\footnotetext{
${ }^{1}$ Id., Article 8(2).

${ }^{2}$ Id., Article 8(1).

${ }^{3}$ Id., Article 8(2).

${ }^{4}$ Id., Article 8(5).

${ }^{5}$ Id., Article 9(1).

${ }^{6}$ Id., Article 9(2a), the institution has also several responsibilities as indicated on the same provision.

${ }^{7}$ COMESA. (2014). Annual Report 2014. COMESA Secretariat, Lusaka. p. 7.

${ }^{8}$ Id., Article 19(1) of the COMESA Treaty.

${ }^{9}$ Id., Article 19(2).

${ }^{10}$ Id., Article 20(1)

${ }^{11}$ Id., Article 20(2)

${ }^{12}$ Id., Article 13(2a)

${ }^{13}$ Id., Article 13(2b)

${ }^{14}$ Id., Article 13(2d)

${ }^{15} \mathrm{Id}$, Article 13(2e)

${ }^{16}$ Id., Article 14(1)

${ }^{17}$ Id., Article 14(2a)

${ }^{18}$ Id., Article 14(2b)

${ }^{19}$ COMESA, Supra note 31 , P. 8
} 


\subsection{The Technical Committees}

The Technical Committees shall be composed of representatives of the member states designated for that purpose. ${ }^{1}$ These committees are responsible for the preparation of comprehensive implementation program and timetables, which serve to prioritize the programs with respect to each sector. ${ }^{2}$ In addition, they monitor and review the implementation of the program on co-operation and may request the secretary-general to undertake specific investigations. ${ }^{3}$ Articles 15(1) of the Treaty stipulate that the Technical Committees of the Common Market shall include the Committee on Administrative and Budgetary Matters, Agriculture, Comprehensive Information Systems, Energy, Finance and Monetary Affairs, Industry, Labor, Human Resources and Social and Cultural Affairs, Legal Affairs, Natural Resources and Environment Tourism and Wildlife, Trade and Customs, Transport and Communications and Statistical Matters.

\subsection{The Secretariat}

The COMESA Secretariat is headed by the Secretary-General, who is appointed by the Authority. ${ }^{4}$ The Secretary General is the Chief Executive Officer of the Common Market and represents the institution in the exercise of its legal personality. ${ }^{5}$ In the exercise of his or her powers, the Secretary-General is required to service and assist the organs of the Common Market in the performance of their functions and, in consultation with the InterGovernmental Committee, submit reports on the activities of the Common Market to the Council and the Authority. ${ }^{6}$

\subsection{The Committee on Peace and Security ${ }^{7}$}

The Member States established a committee comprising senior officials in the Ministries of Foreign Affairs called the "Committee on Peace and Security". This Committee sits at least once a year to discuss the modalities of peace and security in the region. Its recommendations are discussed by the Ministers of Foreign Affairs. The meeting of the Ministers of Foreign Affairs at a policy level agrees on issues on the existing conflicts \& how to address them. The Ministers also discuss post-conflict reconstruction as a way of ensuring conflict prevention. The Authority considers its recommendations $\&$ takes decisions. ${ }^{8}$

\section{RESULTS AND DISCUSSION}

\subsection{Less Diversity in Trade}

Early regional economic groups including COMESA were formed when most of the respective members were implementing import substitution growth strategy. ${ }^{9}$ Moreover the member's exports to their dominant trading partners are primary commodities, coffee being an important one. The only important manufactured product exported being textiles while importing predominantly manufactured goods. ${ }^{10}$ This shows the noncomplementary nature of the intra-COMESA trade which lacks diversification. However, relatively developed countries known for having strong manufactured sector in the economic group such as Egypt and Kenya are in a much better position to market their exports in COMESA but the less developed countries are unable to find significant markets in COMESA. ${ }^{11}$ These asymmetric product complementarities in favor of the more developed members' raises a concern over possible polarization as investment may be attracted towards the larger \& more industrially diversified economies in the region. ${ }^{12}$

\subsection{Overlapped Memberships}

A number of regional arrangements are already in place in the eastern and southern Africa region (COMESA, EAC, SADC, SACU, and IGAD) and most countries are members of more than one such organization. For instance, Dem. Rep. of the Congo which is a member to COMESA is also a member to ECCAS \& SACU while other members of COMESA, Kenya and Uganda are also member to EAC. Overlapping Memberships are a hindrance to regional integration since, among other things, it introduces duplication of effort ${ }^{13}$. Negotiating resources and capacity have been stretched thin across the region. There are administrative costs related to often

\footnotetext{
${ }^{1}$ Article 15(2) of the COMESA Treaty

${ }^{2}$ Id., Article $16(\mathrm{a})$

${ }^{3}$ Id., Article 16(b \& c)

${ }^{4}$ Id., Article 17(1)

${ }^{5}$ Id., Article 17(2)

${ }^{6}$ Id., Article 17(8)

${ }^{7}$ COMESA, Supra note 31, p. 9

${ }^{8}$ Ibid.

${ }^{9}$ Alemayehu \& Haile, Supra note1, p.375

${ }^{10} \mathrm{Ibid}, \mathrm{p} .374$

${ }^{11}$ Khandelwal, Supra note 12, p.17

${ }^{12} \mathrm{Ibid}$

${ }^{13}$ Alemayehu \& Haile, Supra note 1, p.376
} 
complex rules of origin and multiple membership fees are expensive to pay and maintain. ${ }^{1}$ Moreover, there is a variation on the type and the level of political commitment to fulfill regional obligations in relation to their objects.

As noted by Martha, Article 31 of the COMESA treaty and article 16 of the SADC treaties are similar, dealing about the courts (COMESA \& SADC) on finality and conclusiveness of the decisions. If, for example, the COMESA court issues a binding, non-appealable judgment which is contrary to the binding and nonappealable decision of the SADC tribunal concerning the same issue in respect of same parties, reconciling the concurrently binding decisions becomes very difficult thereby adversely affecting intra-regional trade ${ }^{2}$ and interstate relationship between states of COMESA. In this regard, the steps taken by Angola, Lesotho, Mozambique and Tanzania in withdrawing from their membership of COMESA to remain in SADC should be appreciated. ${ }^{3}$

\subsection{The Heterogeneity of the Economies}

Similar to other regional trade arrangements COMESA region is characterized by acute economic imbalances and inequalities. In such scenario some relatively better economies in the region are reaping more economic benefits than others by gaining more of the investments and thus grow significantly faster than the others, exacerbating inequality between. ${ }^{4}$ And this creates hesitation among member countries unless they foresee an immediate benefit from the integration process ${ }^{5}$ Moreover; most counties are concerned about fierce competition from relatively industrialized members such as Kenya, Egypt and Mauritius. ${ }^{6}$ Hence, an integration scheme where countries are at different levels of development with disproportionate gain; it results in the negative impact on domestic economies of less developed countries. Besides, the output of most of the productive sectors in particular, the manufacturing industry (which is characterized by high tariff and import penetration) would likely to decline due to the influx of cheap imports in the local market.

\subsection{Loss of Import-Export Tax Revenue}

Import-export taxes are an important source of government revenue in many Sub-Saharan African countries. Joining free trade area will results in abolishing or substantial reduction of tariffs and this in turn will results loosing revenues contributed by the source. Hence, countries may be more concerned about the loss of revenues because of integration than the medium or long term benefits of integration. ${ }^{8}$ This makes state reluctant from joining those trading regimes or fails to enforce treaty obligations. However this is not always true for all countries. For instance, Ethiopia's revenue loss due to opening its market to COMESA is less than 1 percent of total revenue since its trade with COMESA is negligible. ${ }^{9}$

\subsection{Lack of Political Commitment}

Loss of trade tax revenue stated above added with the absence of compulsory enforcement mechanisms made political leaders to have less commitment in respecting the treaties they signed. ${ }^{10}$ And to the extent that there are different commitments emanating from multilateral, bilateral and regional agreements, countries may give priority to those that entail tangible consequences. ${ }^{11}$ This in turn will erode trust among political leaders, diminish credibility and send wrong signals about policy consistency, which are essential requirements for a dynamically evolving economic integration among national entities. COMESA is engaged in the regional integration process and achieved a Free Trade Area status in 2000. However comparing to other regional trade arrangements intra-COMESA trade was considerably low even within continent attaining $8.7 \%$ on exports \& $11.1 \%$ on imports. ${ }^{12}$ This implies that the commitment to sign regional free trade agreements has not been supplemented with realistic use of the arrangements.

\footnotetext{
${ }^{1}$ Khandelwal, Supra note 12, p.14

${ }^{2}$ Martha, Supra note 10, p.322

${ }^{3}$ David A. (2010). Trade and Globalization: An Introduction to Regional Trade Agreements, Rowman \& Littlefield Publishers Inc as cited by Martha, B. H. (2014). Regional Economic Integration in Africa: Challenges and Prospects. Mizan Law Review, 8(2). p. 321.

${ }^{4}$ Alemayehu \& Haile, Supra note1, p.378

${ }^{5}$ Id., p.379

${ }^{6}$ Ibid.

${ }^{7}$ Cuts international, Supra note 64, p.18

${ }^{8}$ Ghebregergs, Supra note 7, P. 7

${ }^{9}$ Alemayehu \& Haile, Supra note1, p.377

${ }^{10}$ Haile, K. (2000). Regional Integration in Africa: A Review of the Outstanding Issues and Mechanisms to Monitor Future Progress. The African Knowledge Networks Forum Preparatory Workshop. Addis Ababa, Ethiopia. p.13

${ }^{11}$ Ibid

${ }^{12}$ UNECA. (2007). Report to Fifth Session of Committee on Trade \& Regional Integration. UNECA, Addis Ababa. p. 4. The report also revealed that the average import- export intra trade during 2000-2005 accounts 15.8 \& 13.9 in ECOWAS, 15.2 \& 21.5 in IGAD and 33.1 \& 19.9 in SADC on imports and exports, respectively.
} 


\subsection{Loss of national sovereignty}

Joining any FTA leads to a loss of national sovereignty in the design and implementation of trade policies aimed at promoting growth \& development. Joining a FTA may compel members to forge a new policy \& introduce changes to the existing ones so as to increase exports, reduce imports and the trade balance. ${ }^{1}$ FTA has too an implications on social welfare and employment depending on whether or not the country is a net gainer or looser in the arrangement. ${ }^{2}$ With respect to Ethiopia, FTA has been found to increase the inflow of imports and reduce government revenue, resulting in de-industrialization. ${ }^{3}$ This has had social impacts such as job losses especially on the manufacturing sector which is most likely to be affected by liberalization measures. ${ }^{4}$ However the government may take a measure to protect such sensitive sector.

\subsection{Poor Private Sector Participation}

The implementation of the treaties require the understanding, conviction, and confidence of the private sector, an active involvement of this sector in particular and the general public at large ${ }^{5}$ which however been state-centric, confined to a narrow group of political leaders and technocrats in Africa. ${ }^{6}$ There is no or very minimal participation of the general public in discussing integration initiatives. Non-state actors that play key roles in the political economy of Africa are also given limited attention on the issue of integration. ${ }^{7}$ This aspect of the regional integration process in COMESA has been singled out as one of the major weaknesses of the initiative. Likewise in Ethiopia, although it is believed that Civil Society Organizations could play an important role if engaged, there are no established mechanisms to engage in trade policy making and regional trade negotiation processes. ${ }^{8}$ Further, the private sector has not been empowered to take an active and vibrant role in national trade policy making or regional integration. ${ }^{9}$

\subsection{Poor Infrastructure}

In order to attain the vision of becoming a fully integrated, internationally competitive regional economic community infrastructure have a vital role. This is because infrastructure is critical in enabling the production and the conveyance of commodities through the various means of transport and communications. ${ }^{10}$ The infrastructure covers transport, Information Communications Technology, energy and trans-boundary water. The COMESA regional infrastructure challenges result primarily from the lack of resources and capacity within the Member states to enable them to plan, implement and maintain adequate and robust infrastructure networks. ${ }^{11}$ Despite the existence of Poor Infrastructure within member states a report released by COMESA in 2013 on key economic infrastructure projects in the region revealed that comprehensive infrastructures were under construction.

\section{Conclusion}

COMESA intended in progressive realization of integration through preferential trade area arrangement to attain the economic community objectives set in the document. To this end, Member states made specific undertakings to establish a customs union. However challenges such as less diversity in trade, overlapped memberships, heterogeneity of the economies, loss of import-export tax revenue, lack of political commitment, loss of national sovereignty, poor private sector participation, and poor infrastructure are constrained the arrangement from achieving its object.

To avert those problems and to make the arrangement more effective, COMESA Council of Ministers adopted Medium Term Strategic Plan. The arrangement is also accompanying with other arrangements to establish COMESA-EAC-SADC tripartite free trade area but the problem still exists. Therefore, this article found that revisiting the FTA arrangements and member state commitments are among few inevitable solutions to tackle the problem.

\section{Recommendation}

The Balanced Scorecard (2016-2020 COMESA Medium Term Strategic Plan) shall have to be seriously implemented and time shall have to be extended because the strategy arranged to bestow prominent place for

\footnotetext{
${ }^{1}$ Cuts international, Supra note 64, P.19

${ }^{2}$ Ibid

${ }^{3}$ Ibid

${ }^{4}$ Ibid

${ }^{5}$ Id., p.379

${ }^{6}$ Martha, Supra note 10, p.326

${ }^{7}$ Id, p. 326

${ }^{8}$ Cuts International, Supra note 64, P. 22

${ }^{9}$ Id., p. 24

${ }^{10}$ COMESA. (2013). Comesa Region Key Economic Infrastructure Projects. p. 1

${ }^{11}$ Id., p. 4.
} 
environmental safeguards including climate risks which by its nature need some time to react. Since the facilitation, harmonization \& better coordination of trade regimes are major steps to realize Africa's Agenda of 2063 as envisaged in the 1991 Abuja Treaty, the effort to establish the COMESA-EAC-SADC tripartite free trade area shall continue with appropriate attention.

Measures of comprehensive infrastructural expansion by state should have to be stretched to other sectors. The measures taken to withdraw from the arrangement has also vital role in averting the problem of overlapped memberships via substitutive arrangements. On the other hand, Regional integration initiatives shall be open to including non-governmental organizations and individuals.

To avoid hesitation among member countries gainers should compensate losers in the short run and losses are minimized in the long run. Furthermore, the region shall consider implementing further structural transformation to ensure sustainable and inclusive growth through income generation and job creation, diversification of sources of growth, prioritization of people centered growth and promoting decent jobs under programs of rural development, and investment that helps to reduce poverty and inequality.

\section{References}

- Alemayehu, G. \& Haile, K. (2007). Regional Economic Integration in Africa: A Review of Problems and Prospects with a Case Study of COMESA. Journal of African Economies, 17 (3).

- Bridges Africa. (2014, 09 15). Retrieved 05 02, 2018, from https://www.ictsd.org/bridges-news/bridgesafrica/news/ethiopia-envisages-entry-into-the-comesa-free-trade-area

- COMESA. (1993). COMESA, Treaty establishing the common market for eastern and southern Africa.

- COMESA. (2012/2013). Enhancing Intra-COMESA Trade through Micro, Small and Medium Enterprise Development. COMESA Secretariat, Lusaka, Zambia.

- COMESA. (2013). Comesa Region Key Economic Infrastructure Projects. COMESA.

- COMESA. (2014). Annual Report 2014. COMESA Secretariat, Lusaka.

- COMESA. (2016). Medium term strategic plan 2016-2020; In Pursuit of Regional Economic Transformation and Development. COMESA Secretariat, Zambia, Lusaka.

- COMESA. (n.d.). COMESA. Retrieved 05 02, 2018, from http://www.comesa.int/history-of-comesa/

- Cuts International.(2015). From COMESA to TFTA; Integrating the Voice of the Civil Society in Ethiopia. Nairobi.

- Gibb, R. (2009). Regional Integration and Africa's Development Trajectory: Meta theories, Expectations and Reality. Third World Quarterly, 30 (4).

- Haile, K. (2000). Regional Integration in Africa: A Review of the Outstanding Issues and Mechanisms to Monitor Future Progress. The African Knowledge Networks Forum Preparatory Workshop. Addis Ababa, Ethiopia.

- Khandelwal, P. (2004). COMESA and SADC: Prospects and Challenges for Regional Trade Integration (IMF Working Paper).

- Martha, B. (2014). Regional Economic Integration in Africa: Challenges and Prospects. Mizan Law Review, $8(2)$.

- Mehreteab, G. (2013). Integration of the Ethiopian Financial Service Sector through Regional Financial Arrangements: A Step before WTO Accession?'. Law, Social Justice \& Global Development Journal.

- Mwenda, K. K. (1997). The law on regional integration in southern and eastern Africa: threats and prospects. SA Public Law, 12 (2).

- Mengesha, Y. N. (2009). Trade Effects of Regional Economic Integration in Africa: The Case of SADC. Debre Birhan, Ethiopia.

- Patel, C. (2011). Challenges and Opportunities of Regional Trading Agreements in Africa. In R. Modi (Ed.), International Political Economy Series. London: Palgrave Macmillan, South-South Cooperation.

- Tewodros, M. \& Hallelujah L. (2014). Ethiopia; Regional Integration and the COMESA Free Trade Area (Occasional paper 198). South African Institute of International Affairs.

- UNCTAD. (2009). Economic Development in Africa Report 2009: Strengthening Regional Economic Integration for Africa's Development. United Nations Conference on Trade and Development. Geneva: UN Publication.

- UNCTAD. (2018). African Continental Free Trade Area: Challenges and Opportunities of Tariff Reductions (Research Paper No). (Mesut, Ralf \& Christian, Ed.).

- UNECA. (2007). Report to Fifth Session of Committee on Trade \& Regional Integration. UNECA, Addis Abeba.

- UNECA. (2012). Assessing Regional Integration in Africa V:Towards an African Continental Free Trade Area. Addis Ababa, Ethiopia: Economic Commission for Africa. 